\title{
Conjugated serum bile acid concentrations in workers exposed to low doses of toluene and xylene
}

\author{
G FRANCO, G SANTAGOSTINO, M LORENA, M IMBRIANI
}

From the Dipartimento di Medicina preventiva, occupazionale e di comunità dell'Università di Pavia, Fondazione Salvatore Maugeri, Clinica del lavoro e della riabilitazione, IRCCS, Centro di Pavia, Italy

Recent studies of non-halogenated cyclic carbon solvents have shown little evidence of hepatotoxicity, ${ }^{1-3}$ although these negative findings might be explained as a consequence of the incapacity of the existing screening procedures to detect liver changes at an early stage. In fact, the uncertainties regarding the evaluation of liver function have been underlined and the need for simple, non-invasive tests of liver function has been emphasised. ${ }^{4}$ Recently, a relatively new test of hepatic function, the measurement of serum bile acids, has been studied in workers occupationally exposed to a variety of chemicals (styrene, ${ }^{5-8}$ vinyl chloride, ${ }^{69}$ and solvent mixture).$^{610}$

During exposure to toluene and xylene at concentrations below the current TLV-ACGIH, we have studied the behaviour of serum bile acids in relation to environmental concentrations of toluene and xylene and to: indices of internal dose (toluene and xylene in blood and urine) to evaluate the existence of the relation between exposure and effect.

\section{Materials and methods}

A group of 25 workers (mean age 42.3 years, age range 27-50) at a chemical factory producing varnishes and exposed mostly to toluene and xylene (mean exposure duration 10 years, range 5-15) were selected from among 30 subjects using the following criteria:

(1) exposure to solvents for at least two years;

(2) daily ethanol consumption less than $50 \mathrm{~g}$;

(3) no history of hepatic disease;

(4) no drug taken in the previous month.

The survey was performed on a Friday after four days at work. The environmental concentration of solvents in the breathing zone of each subject was measured by means of a personal passive sampler." Samples were analysed according to the methods previously described. ${ }^{12}$ Table 1 shows that there was exposure to toluene and xylene (o, $\mathrm{m}, \mathrm{p}$-isomers) and to isobutyl acetate and methyl isobutyl ketone at low levels.

Table 1 Time weighted individual value $\left(C_{T}\right)$ of solvent exposure

\begin{tabular}{|c|c|c|c|c|c|c|}
\hline & \multicolumn{2}{|c|}{ Median value } & \multicolumn{2}{|c|}{ Geometric $S D$} & \multicolumn{2}{|c|}{$T L V-A C G I H$} \\
\hline & $\begin{array}{l}(m g / \\
\left.m^{3}\right)\end{array}$ & $\underset{\left.m^{3}\right)}{(\mu m o l l}$ & $\begin{array}{l}(\mathbf{m g} / \\
\left.m^{3}\right)\end{array}$ & $\begin{array}{l}\left(\mu^{\mu} \mathrm{moll}^{\prime}\right) \\
\mathrm{m}^{3}\end{array}$ & $\underset{\left.m^{3}\right)}{(m g /}$ & $\underset{\left.m^{3}\right)}{\left(\mu^{3} \mathrm{~mol} /\right.}$ \\
\hline \multirow{3}{*}{$\begin{array}{l}\text { Toluene } \\
\text { Xylene } \\
\text { Isobutyl } \\
\text { acetate } \\
\text { Methyl } \\
\text { isobutyl } \\
\text { ketone }\end{array}$} & $\begin{array}{l}21.5 \\
27.8\end{array}$ & $\begin{array}{l}233 \\
261\end{array}$ & $\begin{array}{l}2 \cdot 4 \\
4 \cdot 5\end{array}$ & $\begin{array}{l}26 \\
42\end{array}$ & $\begin{array}{l}375 \\
435\end{array}$ & $\begin{array}{l}4070 \\
4097\end{array}$ \\
\hline & $12 \cdot 4$ & 106 & $1 \cdot 6$ & 14 & 710 & 6112 \\
\hline & $15 \cdot 8$ & 157 & 1.5 & 14 & 205 & 2046 \\
\hline
\end{tabular}

Urine was collected from the subjects at 0800 (immediately before the beginning of work) and at 1200 (at the end of the half-shift) to measure toluene and xylene concentrations. At 1200 a $10 \mathrm{ml}$ blood sample was taken from the antecubital vein from subjects who had been fasting from 0600 to assess toluene, xylene, and serum bile acid concentrations. Blood samples were also taken at 1200 from 25 controls who had been fasting from 0600 (mean age 44; age range 23-53) chosen from among unskilled workers using the above criteria but with no exposure to solvents or hepatotoxic xenobiotics.

Serum was separated within 20 minutes and kept at $-20^{\circ} \mathrm{C}$ before analysis. Fasting levels of serum conjugated cholic acid (S-CCA) and serum conjugated chenodeoxycholic acid (S-CCDCA) were determined by an immunoenzymatic method (CCA and CCDCA Immunosystem, Sibar, Italy) in which unconjugated cholic and chenodeoxycholic acids had cross reactivities toward the CCA and CCDCA antisera of 5\% and $7 \%$ respectively. The ratio of S-CCA to SCCDCA was calculated.

From the fasting values of the 25 controls the upper limits of the reference range were expressed as the 90th percentile $(1.4 \mathrm{~nm} / \mathrm{ml}$ for S-CCA and $2.4 \mathrm{~nm} / \mathrm{ml}$ for SCCDCA). Statistical evaluation of the results was performed by the Wilcoxon rank sum test for unpaired samples and by $\chi^{2}$. Correlations between serum bile acids and solvents in air $\left(C_{1}\right)$, in blood $\left(C_{b}\right)$, in urine 
Table 2 Median values, 10th $\left(P_{10}\right)$ and 90 th $\left(P_{90}\right)$ percentiles of serum bile acids ( $S-C C A=$ conjugated cholic acid, $S-C C D C A=$ conjugated chenodeoxycholic acid) and their ratio in the exposed group and in controls. Statistical significance with Wilcoxon rank sum test

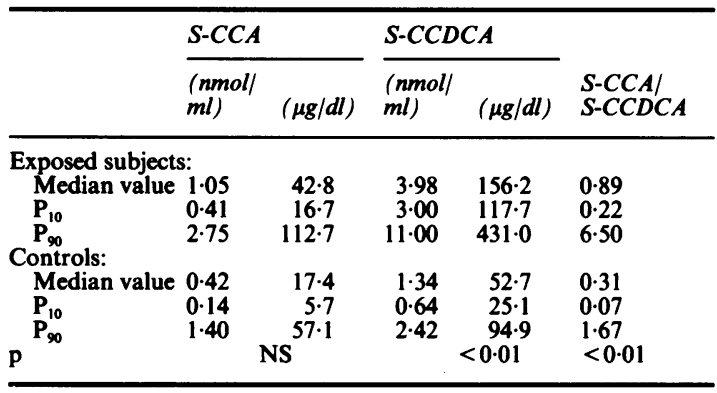

$\left(\mathrm{C}_{\mathfrak{u}}\right)$, and in urine expressed as the difference between the values observed at the end and at the beginning of the half shift $\left(\mathrm{C}_{\Delta \overrightarrow{\mathrm{u}}}\right)$ were calculated.

\section{Results and discussion}

Median serum bile acid values increased in the exposed group but the differences were significant only for SCCDCA and S-CCA/S-CCDCA (table 2). Table 3 shows the prevalence of exposed and unexposed subjects with serum bile acid concentrations above the upper limit of the reference range. S-CCA, S-CCDCA, and the ratio exceeded the cut off value in $32 \%, 80 \%$, and $96 \%$ of the exposed subjects, respectively.

Correlation coefficients of serum bile acids concentration and their ratio, with solvents in air $\left(\mathrm{C}_{\mathrm{T}}\right)$, in blood $\left(\mathrm{C}_{\mathrm{b}}\right)$, and in urine $\left(\mathrm{C}_{\bar{u}}\right.$ and $\left.\mathrm{C}_{\Delta \vec{u}}\right)$ change from -0.24 to 0.19 but are not significant. As in previous reports $^{12}$ a correlation was found between $\mathrm{C}_{\mathrm{T}}, \mathrm{C}_{\tilde{u}}, \mathrm{C}_{\Delta \tilde{\mathrm{u}}}$, and $C_{b}$ ( $r$ values between 0.64 and 0.94 ).

The measurement of serum bile acid concentrations (which is considered as a screening test for liver disease in clinical practice and in the general population ${ }^{13}$ ) has been used to detect early signs of hepatic dysfunction in workers occupationally exposed to various xenobiotics. ${ }^{5-10}$ The results regarding exposure to styrene are contradictory ${ }^{5-8}$ but exposures to solvent mixture $^{610}$ and vinyl chloride ${ }^{69}$ are uniformly associated

Table 3 Prevalence of subjects with serum bile acids concentrations $(S-C C A=$ conjugated cholic acid, $S$ $C C D C A=$ conjugated chenodeoxycholic acid) above the upper limit of the reference range $(1.4 \mathrm{nmol} / \mathrm{ml}$ for $S-C C A$, $2.4 \mathrm{nmol} / \mathrm{ml}$ for $S$-CCDCA, 1.67 for their ratio). Statistical significance with $\chi^{2}$ test.

\begin{tabular}{|c|c|c|c|c|c|c|}
\hline & \multicolumn{2}{|c|}{$\begin{array}{l}S-C C A(\mathrm{nmol}) \\
\mathrm{ml})\end{array}$} & \multicolumn{2}{|c|}{$\begin{array}{l}S-C C D C A \\
(\mathrm{nmol} / \mathrm{ml})\end{array}$} & \multicolumn{2}{|c|}{$S-C C A / S-C C D C A$} \\
\hline & \multicolumn{6}{|c|}{$(\leqslant 1.4)(>1.4)(\leqslant 2.4)(>2.4)(\leqslant 1.67)(>1.67)$} \\
\hline $\begin{array}{l}\text { Exposed } \\
\text { subjects } \\
\text { Controls } \\
\mathrm{p}\end{array}$ & $\begin{array}{l}17 \\
24\end{array}$ & $\begin{array}{r}8 \\
1 \\
<0.01\end{array}$ & $\begin{array}{r}5 \\
24\end{array}$ & $\begin{array}{r}20 \\
1 \\
<0.01\end{array}$ & $\begin{array}{r}1 \\
23\end{array}$ & $\begin{array}{r}24 \\
2 \\
<0.01^{2}\end{array}$ \\
\hline
\end{tabular}

Franco, Santagostino, Lorena, Imbriani with increased concentrations of serum bile acids. The present observations show that exposure to toluene and xylene produces a significant increase in $\$$ CCDCA and in the S-CCA/S-CCDCA ratio.

These observations might be explained by a chan $\overrightarrow{\mathrm{g}}$ in hepatocyte function and, in particular, in one of the various steps involved in bile acid transport. Since the hepatic uptake of bile acids is a sodium dependem carrier mediated process, coupled to the sodiu potassium pump ( $\mathrm{Na} / \mathrm{K}$-ATPase) ${ }^{14}$ xenobiotics thernselves or their metabolites, or both, may be responsible for an impairment of this mechanism (or simply $\vec{a}$ competition with it). Even though this hypothesis is attractive, the lack of any relation between the indicess of doses (environmental, urinary, and blood toluege and xylene) and serum bile acid concentrations remains to be explained.

The measurement of serum bile acid concentrations seems to be helpful in detecting early changes $\underset{\text { of }}{\text { f }}$ hepatic function, even though it needs further valid商tion before being used as an index of effect.

\section{References}

1 Kurppa K, Husman K. Car painters' exposure to a mixture $\frac{O}{\Theta f}$ organic solvents. Scand J Work Environ Health 1982;8:137-49.

2 Waldron HJ, Cherry N, Venables H. Solvent exposure and the liver function. Lancet 1982; ii: 1276.

3 Lundberg I, Håkansson M. Normal serum activities of dive enzyme in Swedish paint industry workers with heavy exp\&ufu to organic solvents. Br J Ind Med 1985;42:596-600.

4 Anonymous. Industrial agents and the liver. Lancet 1 1081-2.

5 Edling C, Tagesson C. Raised serum bile acid concentrations af occupational exposure to styrene: a possible sign of hepatot\&:icity? Br J Ind Med 1984;41:257-9.

6 Vihko R, Vihko P, Maentausta O, Pakarinen A, Janne $尹$ Yrjanheikki E. Assessment of early hepatotoxicity. In: Aitio $\overline{\mathbb{E}}$, Riihimaki V, Vainio $\mathbf{H}$, eds. Biological monitoring $a \AA d$ surveillance of workers exposed to chemicals. Washington: Hemisphere Publ Corp, 1984:309-13.

7 Härkonen H, Lehtniemi A, Aitio A. Styrene exposure and the liver. Scand J Work Environ Health 1984;10:59-61.

8 Bergamaschi E, Mutti A, Ferrari M, et al. Liver damage afd enzyme induction tests among styrene exposed workers. In: Fơa V, Emmett EA, Maroni M, Colombi A, eds. Occupational a environmental chemical hazards. Chichester: Ellis Horwood Lfa; 1987:159-63.

9 Liss GM, Greenberg RA, Tamburro CH. Use of serum bile acidin the identification of vinyl chloride hepatotoxicity. Am J Med 1985;78:68-75.

10 Franco G, Fonte R, Tempini G, Candura F. Serum bile acid concentrations as a liver function test in workers occupationaty exposed to organic solvents. Int Arch Occup Environ Hea 1986;58:157-64.

11 Lauterberger WJ, Kring CV, Morello JA. Theory of passive monitors. In: Kelly WD, ed. Dosimetry for chemical and physidy agents. Cincinnati: American Conference of Governmented Industrial Hygienists, 1977:44-69.

12 Ghittori S, Imbriani M, Pezzagno G, Capodaglio E. The urina concentration of solvents as a biological equivalent exposuese limit for nine solvents. Am Ind Hyg Assoc J 1987;48:786-90.

13 Anonymous. Serum bile acids in hepatobiliary disease. Lancet 1982;ii:1136-8.

14 Blitzer BL, Donovan CB. A new method for rapid isolation 와 basolateral plasma membrane vesicles from rat liver: charaterization, validation and bile acid transport studies. $J B Q^{\prime} l$ Chem 1984;259:9295-301. 